\title{
EFFECTIVE READING STRATEGIES FOR READING SKILLS
}

by:

Dewi Kartika Sari, M.Pd.

Etty Pratiwi, M.Pd.

Ana Theriana, M.Pd.

Lecturers of University of PGRI Palembang

ekamarza@gmail.com

\begin{abstract}
The researchers had found that learning reading strategies is a key element in developing student comprehension. However, many teachers lack a solid foundation for teaching these reading comprehension strategies. Therefore, teachers need to be prepared on how to design effective reading comprehension strategies and how to teach these strategies to their students. Therefore this study aims to study the effective reading strategies in order to improve reading skills in language classes. The study is an action research applied to a number of 15 students in an intermediate level integrated skills course. The main question of the study is "Would reading strategies help my students' reading comprehension studies?". The result od the study indicate that the students had an improvement to a great extend have been tutored about the reading strategies.
\end{abstract}

Keyword: reading strategies, predicting, visualizing, inferring, making connections, questioning, action research

\section{INTRODUCTION}

Reading is a process of interaction between the reader and the material in which all the schematic knowledge being interacted with all the reader's social and contextual factors. Reading skills is the ability of an individual to read, comprehend and interpret written words on a page of an article or any other reading material. The possession of a good reading skill will enable the individual to be able to assimilate a written work within a short period while reading. If an individual develops a reading skill, it is a lifelong activity. And while reading at any given time the individual is expected to also 
think critically on the particular topic or subject to understand the point of the writer. Reading skill can only be developed through constant reading. Inculcating reading culture or habit is a hobby.

According to Anderson, Hiebert, Scott, \& Wilkinson, reading is a basic life skill. It is a cornerstone for a child's success in school and, indeed, throughout life. Without the ability to read well, opportunities for personal fulfilment and job success inevitably will be lost (1985) (please change into the new one) Despite its importance, reading is one of the most challenging areas in the education system. The ever-increasing demand for high levels of literacy in our technological society makes this problem even more pressing (Snow, Burns, \&Griffin, 1998). Students' attitudes regarding the pruposes for reading also influence their ability to read. If students want to get the most out of the materials they are assigned, they have to learn to read critically or analytically. The idea here is that when we read something, the purpose is to try to understand what the au th or 's intention is. When dealing with reading, we encounter two layers of reality: one that we can see and one that we cannot see. Therefore, the purpose of reading is to make the invisible layer, the underlying meaning, visible and clear (Kose 2006). Teele asserts that the goal of all readers should be to understand what they read (2004, p. 92). Research shows good readers are actively involved with the text, and they are aware of the processes they use to understand what they read. Teachers can help improve student comprehension through instruction of reading strategies. Predicting, making connections, visualizing, inferring, questioning, and summarizing are strategies shown by research to improve reading comprehension (Block \& Israel, 2005). It is important to teach the strategies by naming the strategy and how it should be used, modelling through the think-aloud process, group practice, partner practice, and independent use of the strategy (Duke \& Pearson, 2005).

\subsection{Predicting}

First strategy for improving reading comprehension is predicting, which helps the reader set a purpose for their reading. Research has shown that good readers use their experiences and knowledge to make predictions and formulate ideas as they read (Block \& Israel, 2005). This strategy also allows for more student interaction, which increases student interest and improves their understanding of the text (Oczkus, 2003). It is 
important to compare the outcome in the actual text with the prediction process as it will lead the learner to improve his understanding.

Without this aspect of the prediction process, it becomes meaningless to improving the students's comprehension (Duke \& Pearson, 2005). Some of the approaches for teaching predicting are teacher modeling, predicting throughout the text; with partners, with a graphic organizer, or using post-it notes throughout the text. Using the title, table of contents, pictures, and key words is one prediction strategy. Another key prediction strategy is to have students predict at specific points through the text, evaluate the prediction, and revise predictions if necessary (Teele, 2004).

\subsection{Visualizing}

Another strategy that the good readers employ when comprehending a text is visualization (Adler, 2001). Visualization requires the reader to construct an image of what is read. This image is stored in the raders's memory as are representation of the reader's interprtation of the text (National Reading Panel, 2000). Teachers can motivate students to visualize settings, characters, and actions in a story and ask them to make drawings or write about the image that come to their minds after visualizing the text.

\subsection{Making Connections}

Making connections is another strategy that can be used in the reading process. By making connections, the learners can activate their prior knowledge and connect the ideas in the text to their own experiences. Reading becomes meaningful when the reader connects the ideas in the text to their experiences and beliefs, and the things happening in the outer world. "Text-to-Text, Text-to-Self, Text-to-World" is a strategy that helps students make connections. Students can make text-to-self connections through drawing, making a chart, or writing. Teachers might ask students if they have ever experienced anything like the events in the text. Students can make text-to-text connections through drawing, making a chart, writing, and graphic organizers. These text-to-text connections could be based upon how characters in the story relate to each other, or how story elements relate between stories. Students can make text-to-world connections through drawing, making a chart, writing, or graphic organizers. Text-toworld connections could be done by comparing characters in a story to characters today or comparing the content of the text to the world today (Teele, 2004). Giving a purpose 
to students, reading by asking thm to find connections would help them comprehend the ideas better in the text.

\subsection{Summarizing}

The process of summarization requires the reader to determine what is important when reading and to condense the information in the readers own words (Adler, 2001). During the summarizing process, the students will be able to distinguish the main ideas from the supporting ideas.Distinguishing the relatedknowledge from the unrelated onesis another point in the summarizing process which will help the students' capacity to improve text comprehension. Summarizing is a strategy which helps the students to organize the ideas even in the long reading passages which are usually perceived as threat for the students.

\subsection{Questioning}

Readers can use the questioning before, during, and after reading. The questioning process requires readers to ask questions of themselves to construct meaning, enhance understanding, find answers, solve problems, find information, and discover new information (Harvey \&Goudvis, 2000). In this strategy, the students return to the text throughout the reading process to find the answers to the questions asked by the teacher before, during and after the reading.By this strategy, students practice to distinguish between questions that are factual inferred or based on the reader's prior knowledge. By using the student generated questioning strategy; text segments are integrated and thereby improve reading comprehension (NRP, 2000).

\subsection{Inferring}

Inferring refers to reading between the lines. Students need to use their own knowledge along with information from the text to draw their own conclusions (Serafini, 2004). Through inferring students will be able to draw conclusions, make predictions, identify underlying themes, use information to create meaning from text, and use pictures to create meaning (Harvey \& Goudvis, 2000). Students can be given techniques to use illustrations, graphs, pictures, dates, related vocabulary and titles from the text to make inferences.

\section{Please add some reviews of literature}




\section{ACTION RESEARCH QUESTION}

This research is to improve reading comprehension through the use of reading strategies. The teacher researcher believes that without a solid foundation of reading strategies the students will struggle throughout their academic and adult life. The researcher hopes to provide reading awareness to her students by teaching reading comprehension strategies and by this way the studetnts will develop a more meaningful reading experience. The research question is, "Would reading strategies help my students' reading comprehension studies?". The purpose of this study was to analyze the improvement of the students reading skills after they have taken presentations on reading strategies.

\section{METHOD.}

Reading proficiency is the most fundamental skill for academic learning and success in school. According to a study done in the United States, the ability to read proficiently is significantly related to how much a person can achieve in his or her personal and professional life (Block \& Israel, 2005). It is for this reason that I have decided to do this action research. According to Brown and Dowling (2001), action research is a term which is applied to projects in which practitioners seek to effect transformation their own practices..." Generally an action research is carried out in a school setting. Corey (1953) believed that the value of action research is in the change that occurs in everyday practice rather than the generalization to a broader audience. Action research is a reflective process and it deals with the practical concerns that are close to the instructors and allow them to make a change. The main aim of an action research is to find solutions to real problems faced in schools and searching ways to improve student success. The process of action research assists educators in assessing needs, documenting the steps of inquiry, analyzing data, and making informed decisions that can lead to desired outcomes. Simply the stages of an action research are, (McNiff, 1988: 22);

\section{- Planning}


- Acting

- Observing

- Reflecting

Research results show that students improve comprehension when they analyze which strategy they are using and how it helps bring meaning to the text.

\subsection{Data collection instrument and the process of the research}

The objective of this research project was to find out the reading awareness level of the students and improve their reading strategies. The teacher researcher used six strategies; predicting, making connections, visualizing, inferring, questioning, and summarizing. The strategies were introduced to the students and prcticed for three weeks. First the research teacher applied a "Reading Awarness Survey" in order to find out if the students were aware of the strategies. The result of the study, pointed out that 9 of the 15 students were not aware of the strategies. First the strategies were modeled by the teacher researcher and as the second step the strategies were practiced by the whole class, then small groups, and finally independently. Following the presentation of the reading strategies, the teacher researcher administered the Metacomprehension Strategy Index (MSI) to see if the strategies presented have changed students' understanding in reading. The index is a tool which measures students, familiarity about reading strategies used before, during, and after reading. The teacher researcher then practiced four reading texts from the coursebook "Hemispheres" for four weeks.

\section{RESULTS AND CONCLUSION}

The results of the reading awareness scale and my personal experience showed thatthere was a lack of knowledge in the area of reading strategies in my students at the beginning of the study. The students had a lack of knowledge and practice in reading strategies however after a comprehensive study, there was an improvement in their success. At the beginning as being the researcher, we had some worries about how to implement the strategies in the classroom. The number of the strategies was another obstacle as the students might have found them confusing. Another question in mind was about the success of the students' using the comprehension strategies indepndntly as many of these reading comprehension strategies were new to the students. In order to overcome this situation, we had to guide and monitor the students in every step of the 
process especially for the questioning, inferring, and summarizing strategies. After an intensive study we have experienced the improvement in my students. This research journey was quite rewarding both for my students and us. The results of the action research gave me the confidence about how to integrate the strategies into our curriculum. As for the students; they developed a better understanding of the strategies and their comprehensions in reading have improved. The action research was a productive experience; now that we have seen an increased understanding of reading comprehension strategies and an improvement in reading comprehension of our students, we would like to continue using these strategies in our curriculum.

\subsection{Implications}

Future research on the revised reading strategies will probably include a larger random sample. Different instruments such as using check list in order to write down the improvement of each student in weekly bases on participation and the strategies they use more commonly can also be noted by the researcher. Also other researchers may want to explore metacomprehension differences between female and male students. In preparatory school groups students in different levels of English can also be examined in order to see the differences in competence in English. Examining a larger group of students would give a better understanding about the differences. This study can also be applied to two different groups by two different researchers and the results can be compared.

\section{REFERENCES}

Adler, C. R. (Ed.). (2001). Put reading first: The research building blocks for teaching children to read. Jessup, MD: ED Pubs.

Anderson, R., Hiebert, E., Scott, J., \& Wilkinson, I. (1985).Becoming a nation of readers: The report of the commission on reading. Washington, DC: National Institute of Education and the Center for the Study of Reading.

Block, C. \& Israel, S. (2005). Reading first and beyond: The complete guide for teachers and literacy coaches. Thousand Oaks, CA: Corwin Press. 
Brown, A., \& Dowling, P. (2001).Doing research/reading research: A mode of interrogation for teaching. London, England: Routledge Falmer.

Corey, S. M. (1953). Action research to improve school practices. New York, NY: Teachers College Press.

Duke, N. K. \& Pearson, (2005).Effective practices for developing reading comprehension. Retrieved from http://www.ctap4.org/ infolit/trainers/comprehe_strategies.pdf

Harvey, S., \& Goudvis, A. (2000).Strategies that work teaching comprehension to enhance understanding. York, ME: Stenhouse Publishers.

Kose, N. (2006). Effects of portfolio implementation and assessment critical reading on learner autonomy of EFL students. Retrieved from http://www.belgeler.com/blg/12ta/effects-of-portfolio-implementation-and-assessmenton-critical-reading-and-learner-autonomy-of-elt-students

National Reading Panel. (2000). Comprehension III teacher preparation and comprehension strategies instruction. (Chap.4). Retrieved from http://www.nichd.nih.gov/publications/nrplch4-111.pdf

Oczkus, L. D. (2003). Reciprocal teaching at work strategies for improving reading comprehension. Newark, DE: International Reading Association.

Serafini, F. (2004). Lessons in comprehension explicit instruction in the reading workshop. Portsmouth, NH: Heinemann.

McNiff, J. (1988). Action research: principles and practice. London, England: Routledge. 
Teele, S. (2004).Overcoming barricades to reading a multiple intelligences approach. Thousand Oaks, CA: Corwin Press.

Note:

1. Please make into two column all the paragraph, then make sure it the references stated on the paper.

2. Please make it into two format (word and pdf format) and resend again into esteem email.

3. The total number of the page should be only about 8-12 pages.

Sincerely yours,

Editor Chief 